\title{
The Influence of Commitment on State Civil Apparatus in the Governor Office of South Sumatera
}

\author{
Sopian.A.R ${ }^{1}$, Ardiyan Natoen ${ }^{1}$, Indra Satriawan ${ }^{3}$, Periansya ${ }^{1, *}$ \\ ${ }^{I}$ Departement of Accounting, Politeknik Negeri Sriwijaya, Palembang, Indonesia \\ "Corresponding author. Email: periansya @ polsri.ac.id
}

\begin{abstract}
This research is conducted to know how competence, work motivation, leadership and commitment from civil apparatus to the responsibilities he carries in carrying out the task. The research itself was conducted with an explorative discourse approach using a sample of the state civil apparatus on the Office of the Governor of South Sumatera province. In this study, the analysis techniques used multiple linear regression, in addition, to carried out partial tests and F. From the results of analysis are known that the competency has no effect positive and significantly against the commitment of civil apparatus while the state And leadership have a positive and significant impact on the commitment of state civil apparatus. Furthermore, when tested simultaneously, it is known that the three variables are significantly influential. The conclusion of this research is the necessity of synchronization between competencies and the commitment of the civil apparatus of the state in carrying out government duties, especially in terms of competence so that the employees can realize the commitment and ultimately Employee performance.
\end{abstract}

Keywords: competence, motivation, leadership, commitment

\section{INTRODUCTION}

The good government is the peace of every Indonesian people as the manifestation of the 4th paragraph of the opening of the state Constitution of the Republic of Indonesia in 1945, which is to build a state that is as real, fair and prosperous. To realize the above, in need of state civil apparatus (ASN) or civil state apparatus is professional and free from the political and clean interests of the practice of corruption, collusion, and nepotism. As a servant and civil servants, the public administration of civilian apparatus must be able to be transparent and accountable in carrying out its functions. Besides being a community servant, the role of ASN is as a state servant in achieving the ideals of the nation.

In conducting the development of the civil apparatus of the state with the government regulation that in carrying out its role should work effectively, efficiently, discipline, professional and accountable so that the development in the way will be able to achieve with maximum (PP53/2015). The impact arising from the empowered work can bring positive results for the development results that have been poured in the regional medium-term Builders plan (RPJMD) by referring to the National Secondary Development Plan (RPJMN).

The work plan outlined in the RPJMD will be implemented by the State civil apparatus for successful development. To support the success of regional development, there is a dedicated bureaucratic performance on each regional device organization (OPD). To produce optimal performance, it is required that the continuous reform is implemented which is an element of the non-physical development of a government. When the current accuracy and objectives in the work program are considered a problem.

Good governance will result in a good government performance that must be supported by a qualified organization concerning factors such as human resources, capital, machinery, and other resources. But this performance can be realized if there is a high commitment to running the organization. A high commitment will be realized if each state apparatus can understand the objectives of the Organization. With optimal commitment, the preservation will be able to produce optimal performance.

In addition to the high commitment, a good government needs to support the leadership and motivation of the country's apparatus. Leadership and good commitment need adequate competence to achieve the expected performance. Current regional governments by central government regulations are allowed to provide income improvement allowances as an effort to increase revenues. Success in the implementation of local government work is not separated from competence, commitment and leadership as well as the motivation of civil servants [1], [2] which is owned by the officer and commitment as part, not In performance. Competence [3] can give added value to the work done by the officers in achieving the desired performance as well as the leadership [4] that can be a good nurturing and directing subordinates in measurable performance achievements including leaders can motivate subordinates to work seriously including the employee's commitment to perform their work selflessly.

From the data obtained that currently indicates that the quality of public service has not shown the optimal figure visible from the new public satisfaction index at the value 
of $\mathrm{B}+$, the new Community Satisfaction Index in value B. In addition to being viewed from the accountability Performance of the Government of South Sumatera is also not optimal where the value of SAKIP District/city average $\mathrm{B}$, and $\mathrm{CC}$, there is no $\mathrm{A}$. This indicates that the community has not gained any satisfaction in dealing with local government agencies. Not optimal service also seen in research [5] which is due to the culture of discipline and incentives.

This research aims to see if the competency factor, leadership, motivation affect the commitment of the State civil apparatus that is the cause of the low quality of public service in the office of the Governor of South Sumatra province.

\section{LITERATURE REVIEW}

\subsection{Leadership}

In the theory of leadership, it is said the process of influencing people can be achieved by through selfmotivation. That leadership is a person's ability to influence others to achieve its objectives [6]. Therefore, leadership if widely interpreted include influencing processes in determining the objectives of the organization, motivating the behavior of the followers to achieve the objectives, influencing to improve the group and its culture in a matching [7] That the leadership is meant as a process that can direct and also affect other parties who have a job relationship.

To achieve the goal in the leadership of at least three things to note that the first leaders involve others either subordinates or their followers, the second is distributing the power he held and the third able to Influence and mobilize their followers in various ways.

Unwittingly that every leader carries his style, where the style is a norm he uses when it affects the attitudes of others including his subordinates. At present, there are at least two approaches in leadership[7] [8] First approach to transactional leadership (transactional leadership) and Transformational leadership.

A transformational leader's approach is more inclined towards evaluating the ability and potential of each subordinate to perform tasks and at the same time see the possibility to broaden subordinate responsibilities and authority in the future. Conversely, transactional leaders are subject to achievement of goals or objectives but do not seek to develop subordinate responsibilities and authority for subordinate progress. Thus, the difference between the two approaches above. The transformational leader can be interpreted to unite all of his subordinates and able to change the comfort, attitudes and personal goals of each subordinate to achieve the goal, even exceeding the set goals [9].

\subsection{Competence}

Competence [10] [11] can be interpreted as an ability that is possessed by someone in carrying out its work or tasks based on knowledge, skills and work attitudes required by the job. Competence can be interpreted as an ability of intellectual ability to solve a problem. Also, if further studied that competence is the basic characteristics that a person needs to have that can directly influence the capacity of performance in completing the task at its own. Likewise [12] hinting that one's workability should refer to the individual capacity to work on the various tasks entrusted to him.

\subsection{Commitment}

Commitment [11] as a relative force for the individual to its organization. The relative strength that exists is a manifestation of a strong relationship with the love of the organization. Each worker must be able to identify an organization with the intent and purpose and hope to remain part of the member of the organization.

Meyer, Allen, and Smith [14] mention three-dimensional commitments in organizing, namely Affective Commitment, Continuance Commitment, and Normative Commitment. These three dimensions relate well to members ' emotional relationships to their organization, identify with organizations, and member involvement with activities in the Organization then awareness of organizational members so that they will suffer losses If leaving the organization and the latter is describing a feeling of attachment to continue to be in the organization. Members of the organization with the high normative commitment will continue to be members in the organization because it feels he must be in the organization. Employees who have a high commitment to an organization will have the loyalty and sense of having an organization; Have a strong desire to keep joining the organization; Then engaged earnestly in his work, and displaying behaviors that are appropriate for the organization's purpose. These three commitments belong to the realm of attitudes or affective commitments that relate to the extent to which a person feels his or her personal goals and objectives are following the objectives of the Organization.

\subsection{Motivation}

Motivation means to move or movement [15][16], motivation means a condition of individual will in the NFM to move or cause a person to do a deed/activity, which takes place Consciously. Also as a force of resources that move and control human attitudes. The motivation of an effort that can encourage a person to take the desired action, while the motive as the impulse of a person to do. Because a person's behavior tends to be 
oriented toward purpose and encouraged by the desire to achieve a particular goal.

It can be said that motivation is a thrust that is governed by purpose and rarely appears in the void. Words of need, desire, desire, and encouragement are all similar to motives, which are the origin of the word of motivation. Understanding motivation is very important because performance, reaction to compensation, and other human resources issues are influenced by and influence motivation. Motivation is a complex problem in the organization because the needs and desires of each member of the organization differ from one another. This is different because each member of an organization is uniquely biologically and psychologically, and develops based on different learning processes.

The success of an organization is believed to depend heavily on its employees. If you do not have a concern for the job, then the officer will not try to do the job appropriately and productively. Motivation to be the driving force to work and Excel, and which is the basis of designing work to be interesting, so that employees will do their job.

\section{RESEARCH METHODS}

\subsection{Types of research}

The type of research used in this study is quantitative research. Quantitative research is one of the types of research used to examine certain populations or samples with quantitative data statistics and aims to test a predetermined hypothesis. This research is conducted by providing questionnaires directly to the civil apparatus of the state in South Sumatera province.

\subsection{Population and Sample}

The population in this study are ASN (state civil apparatus) in the office of the Governor of South Sumatera province. In this study, the technique is used to determine the sample through the Purposive sampling method. The purposive sampling method is a sampling technique with certain criteria. The criteria in this study were that the respondents were the parties directly involved in the activities of personnel, finance and other technical activities where the respondents have educated at least strata one. The number of questionnaires were distributed for 130 respondents and returning as many as 116 respondents.

\subsection{Variable Research}

Variables in this study consist of independent variables and dependent variables. Independent variables in this study are competence, leadership, motivation. While the dependencies variable is commitment.

\subsection{Research Model}

This Model of research uses multiple linear regression. The models in this study are:

$\mathrm{Y}=\mathrm{A}+\mathrm{bX} 1+\mathrm{bX} 2+\mathrm{bX} 3+\mathrm{E}$

Description:

$\mathrm{Y}=$ Commitment

$\mathrm{A}=$ Constants

$\mathrm{b}=$ Coefficient of regression

$\mathrm{X} 1$ = Competency Variable

$\mathrm{X} 2$ = motivation Variable

X3 = Leadership Variables

$\mathrm{E}=$ Error

\subsection{Data Analysis Techniques}

The method of data analysis techniques in this study are:

1. Descriptive statistics

2. Classic Assumption Test

3. Test normality

4. Autocorrelation Test

5. Multicolinearity Test

6. Heteroscadasticity Test

7. Coefficient of determination

8. Hypothesis Test

9. Test statistics T

10. Test statistics F

\section{RESULTS AND DISCUSSION}

\subsection{Test normality}

Test data normality is used to know the data is distributed normally or not. This test uses the graphing method and statistical test method of One-Sample Kolmogorov Smirnov. The graph method is to see the spread of data on the diagonal source on the Normal P-P Plot of regression standardized residual graph. As the basis of its decision, if the dots spread around the line and follow the diagonal line, the residual value is normal. One Sample test method Kolmogorov Smirnov with significance value $>0.05$ then data distribution is normal, and if the significance of the < 0.05 is not a normal distribution data.

Data normality testing is performed by viewing the data spread (dots) on the diagonal axis of the graph. The basis of decision making is that if the data spread around the diagonal line and follows the direction of the diagonal line, then the regression model meets the normality assumption. In the 4.1 images it appears that the dots are spreading 
around the diagonal line, as well as the spread following the direction of the diagonal line.

So it can be concluded that based on the graph probability plot, the regression model fulfills the assumption of normality which means that the data in this study comes from a population that is normally distributed, so this regression model deserves to be used to predict Successful commitment based on its independent variable input: competence, motivation, and leadership.

Besides, the test results of normality than shown by the Normal graph of P-P Plot of regression standardized residual and Normal Histogram chart can also be supported using the Kolmogorov-Smirnov test. The results of One-Sample test Kolmogorov-Smirnov Test in table 1 indicates that the value of Asymp. SIG (2-tailed) residual in this study has a value greater than 0.05 which amounted to 0.092 for competency variables, motivation, leadership, and commitment. Thus the regression model in the study has been distributed normally so that the available data can be used for regression analysis and can be concluded that regression models on this study have fulfilled the assumption of normality.

\subsection{Multicolinearity Test}

The multicolinearity test aims to test whether in a regression model found the correlation between independent variables. A good regression model should not correlate with each free variable. A good regression model should not correlate with each free variable.

Tabel 1 Multicollonierity Test

\begin{tabular}{|c|c|c|c|c|c|c|c|c|}
\hline \multicolumn{9}{|c|}{ Coefficients $^{\mathrm{a}}$} \\
\hline & & \multicolumn{2}{|c|}{ Unstandardized Coefficients } & \multirow{2}{*}{$\begin{array}{c}\text { Standardized Coefficients } \\
\text { Beta }\end{array}$} & \multirow[b]{2}{*}{$\mathrm{T}$} & \multirow[b]{2}{*}{ Sig. } & \multicolumn{2}{|c|}{ Collinearity Statistics } \\
\hline \multicolumn{2}{|c|}{ Model } & $\mathrm{B}$ & Std. Error & & & & Tolerance & VIF \\
\hline \multirow[t]{4}{*}{1} & (Constant) & $-3,448$ & 6,112 & &,- 564 & ,574 & & \\
\hline & Competence & ,082 &, 077 & ,078 & 1,061 & 291 & ,920 & 1,086 \\
\hline & Motivation & 632 & 092 &, 523 & 6,887 & 000 & 862 & 1,160 \\
\hline & Leadershp & 254 & ,081 & ,248 & 3,147 & ,002 & ,801 & 1,248 \\
\hline
\end{tabular}

Source: Processed Data, 2019.

According to table 1, it can be noted that the X1 variable tolerance value is 0.920 or more than 0.10 and the variable $\mathrm{X} 1 \mathrm{VIF}$ value is 1.086 or smaller than 10 . The tolerance variable value of $\mathrm{X} 2$ is 0.862 or greater than 0.10 and the value of the VIF variable X2 is 1.160 or smaller than 10 . The value tolerance of the $\mathrm{X} 3$ variable is 0.801 or greater than 0.10 and the VIF variable $\mathrm{X} 3$ value is 1.248 or smaller than 10. It can be concluded that there is no Multicolinearity problem between the variables in this study.

\subsection{Heteroscedasticity test}

Heteroscedasticity is a condition in which a regression model occurs a variant inequality of the residual on one observation to another observation. The heteroscedasticity test is seen with a plot graph (scatterplot) in which the spread of the dots caused randomly forms, does not form a specific pattern and the spread direction is above or below 0 on the $\mathrm{Y}$-axis. If the point spread forms a specific pattern, heteroscedasticity occurs.

From the calculate it can be known that the dots are spreading randomly and not forming certain patterns that are orderly and clear. The dots spread above and below the number 0 on the Y-axis. So it can be concluded that there is no heteroscedasticity problem or in other words does not occur similarity variant of the residual on one observation to another observation in the model Regression.

\subsection{Multiple linear regression analysis}

Based on tabel 1 the calculation of multiple linear regression between human resources competency, motivation, and leadership with SPSS program (Statistical Product and Service Solution) obtained the following results that the regression equation can be interpreted:

1. The constant value of 3,448 indicate that if the independent variable of competence, motivation, and leadership is 0 , then the commitment of-3.448.

2. Variable regression coefficient competence of, 0.082 positive value indicates the relationship between the competency variable and the commitment variable which means if the value of competency variable is up by 1 then the value of commitment will rise Amounting to, $082 \%$. Assuming other free variables are constant

3. Variable regression coefficients of motivation, 0. 632 positive value indicates a direct connection between the variable motivation with commitment variable which means if the value of the motivation variable rises by 1 then the value of commitment will increase by, $632 \%$. Assuming other free variables are constant.

4. The variable regression coefficient of the leadership of 0.254 positive value indicates a direct relationship between the leadership variable and the commitment variable which means if the value of leadership variables rises by 1 then the value of commitment will 
rise Amounting to, 254\%. Assuming other free variables are constant.

\subsection{Coefficient of determination test $\left(R^{2}\right)$}

Table 2 Coefficient of determination test Result $\left(\mathrm{R}^{2}\right)$

\begin{tabular}{|l|c|r|r|r|r|}
\hline \multicolumn{9}{|c|}{ Model Summary $^{\mathrm{b}}$} \\
\hline Model & \multicolumn{1}{|c|}{$\mathrm{R}$} & \multicolumn{1}{|c|}{ R Square } & \multicolumn{1}{|c|}{ Adjusted R Square } & \multicolumn{1}{c|}{ Std. Error of the Estimate } & \multicolumn{2}{c|}{ Durbin-Watson } \\
\hline 1 &, $667^{\mathrm{a}}$ &, 444 &, 429 & 3,717 & 1,409 \\
\hline
\end{tabular}

a. Predictors: (Constant), Competence, Motivation ,Leadership

b. Dependent Variable: Commitment

Source: Processed Data, 2019.

Based on the calculate it is known that multiple regression test results are obtained a double correlation coefficient (R) of, 667 or as of $66.7 \%$, and an R2 value of 0.444 . Thus the magnitude of influence given by the variable of competence, motivation, and leadership is $44.4 \%$. While the remaining $55.6 \%$ is influenced by other factors that are not examined in this study which is not mentioned. The Adjusted value of R Square is 429 . It also demonstrates the contributing influence of competence, motivation, and leadership variables by $42.9 \%$. While the remaining $57.1 \%$ is influenced by other factors that are not examined in this study which is not mentioned

\subsection{Hypothesis Test}

\subsubsection{Partial significance test (test-T)}

Partial testing (test-t) of each independent variable: competence, motivation, and leadership are conducted to test acceptable or rejection a proposed hypothesis. The result of the regression output with SPSS will show the count and its significance values.

The significance of each variable can be seen from the Tcount and T-table values of each $\mathrm{X}$ variable. If the value of $\mathrm{T}$ count $>$ This then individually (partial), the variable $\mathrm{x}$ can be expressed to have a significant effect on the variable $\mathrm{Y}$, and if the value of $\mathrm{T}$ count $<$ The variable $\mathrm{X}$ individually does not have a significant effect on the $\mathrm{Y}$ variables. Based on table 1 shows that for the variable competence, Motives, and leadership, each is:

1. Hypothesis 1 Testing (competence)

From the output, SPSS obtained T count of 1,061 . To specify a searchable query at significance $0.05 / 2=$ 0.025 (2-sided test) with a degree of freedom $\mathrm{DF}=\mathrm{N}$ $\mathrm{K}-1$ or $116-3-1=112$ ( $\mathrm{n}$ is the amount of data and $\mathrm{K}$ is the number of independent variables). Results are obtained for a This of 1,9812/-1,982 (see the Statistics table). Because the value of $<\mathrm{T}$ count $(1.982<1.061)$ then $\mathrm{H} 1$ is rejected. Based on significance, if the significance of $<0.05$ then $\mathrm{H} 1$ is accepted, and if the significance of $>0.05$ then $\mathrm{H} 1$ is rejected. Because of the significance on the T-test more than $0.05(0.291>$
0.05) then $\mathrm{H} 1$ is rejected. So can be obtained the value of $\mathrm{T}$ count 1,982 with a significance value of 0.291 , then it can be concluded that the competency is partially no effect and not significant to the quality of commitment.

2. Hypothesis 2 Testing (motivation)

From the output, SPSS obtained T count of 6.887. To specify a searchable query at significance $0.05 / 2=$ 0.025 (2-sided test) with a degree of freedom $\mathrm{DF}=\mathrm{N}$ $\mathrm{K}-1$ or $116-3-1=112$ ( $\mathrm{n}$ is the amount of data and $\mathrm{K}$ is the number of independent variables). Results are obtained for a This of 1,982/-1,982 (see the Statistics table). Because the value of $\mathrm{T}$ count $>$ This $(6.887>$ 1.982) then $\mathrm{H} 2$ is accepted. Based on significance, if the significance of the $<0.05$ then $\mathrm{H} 2$ is accepted, and if the significance of $>0.05$ then $\mathrm{H} 2$ is rejected. Because of the significance on the T-test is less than $0.05(0.000<0.05)$ then $\mathrm{H} 2$ is acceptable. So it can be obtained the value of $\mathrm{T}$ count 6.887 with a significance value of 0.000 , then it can be concluded that the motivation partially influential positive and significant to the commitment

3. Hypothesis 3 Testing (leadership)

From the output, SPSS obtained T count of 3.147. To specify a searchable query at significance $0.05 / 2=$ 0.025 (2-sided test) with a degree of freedom $\mathrm{DF}=\mathrm{N}$ $\mathrm{K}-1$ or $116-3-1=112$ ( $\mathrm{n}$ is the amount of data and $\mathrm{K}$ is the number of independent variables). Results are obtained for a This of 1,982/-1,982 (see the Statistics table). Because the value of $\mathrm{T}$ count $>$ This (3.147 > 1.981) then the $\mathrm{H} 3$ is accepted.

Based on significance, if the significance of the $<0.05$ then the $\mathrm{H} 3$ is acceptable, and if the significance $>0.05$ then the $\mathrm{H} 3$ is rejected. Because of the significance on the T-test less than,002 $(, 002<0.05)$ then the H3 is accepted. So can be obtained $\mathrm{T}$ count value of 3,147 with the significance value of, 002 , then it can be concluded that the leadership partially influential positive and significant to the commitment. 


\subsubsection{Simultaneous significance test (test-F)}

The $\mathrm{F}$ test is essentially used to indicate whether all independent variables included in the research model have a simultaneous influence or together against the dependent variable. If the level of significance is $<0.05$ and $F$ count is more $>$ than $f$ table, it can be inferred there is a shared influence between the independent variables $(\mathrm{X})$ of the dependent variable $(\mathrm{Y})$.

Table 3 Simultaneous significance test (test-F)

\begin{tabular}{|c|c|c|c|c|c|c|}
\hline \multicolumn{7}{|c|}{ ANOVA $^{\text {a }}$} \\
\hline \multirow{2}{*}{1} & Model & Sum of Squares & df & Mean Square & F & Sig. \\
\cline { 2 - 7 } & Regression & 1237,012 & 3 & 412,337 & 29,844 &, $000^{\text {b }}$ \\
\cline { 2 - 7 } & Residual & 1547,436 & 112 & 13,816 & & \\
\cline { 2 - 7 } & Total & 2784,448 & 115 & & & \\
\hline \multicolumn{2}{|l}{ a. Dependent Variable: Commitment } \\
\multicolumn{2}{|l}{ b. Predictors: (Constant), Competence ,Motivation, Leadership } \\
\hline
\end{tabular}

Source: Processed Data, 2019.

Based on table 3 the $\mathrm{F}$ test results can be known $\mathrm{f}$ calculate by 29.844 . To specify the $f$ table, it can be seen in the statistics table at significance level 0.000 with DF 1 (number of variables-1) $=3$, and DF $2(\mathrm{~N}-\mathrm{K}-1)$ or $116-3-1$ $=112(\mathrm{n}$ is the amount of data and $\mathrm{K}$ is the number of independent variables). Results were obtained for $\mathrm{F}$ Table 1 of 2.685 (see in the Statistics table). Because F count > F Table (29.844 > 2.685) then H4 is accepted.

Based on significance, if the significance is $<0.05$ then $\mathrm{H} 4$ is accepted, and if significant $>0.05$ then $\mathrm{H} 4$ is rejected. Because of the significance in the $\mathrm{F}$ test less than 0.05 $(0.000<0.05)$ then the $\mathrm{H} 4$ is acceptable. So it can be obtained the value of $\mathrm{F}$ count of 22.883 with a significance value of 0.000 , then it can be concluded that competence, motivation, and leadership jointly positively and significantly influence the commitment.

\subsection{Discussion}

\subsubsection{Effect of competency on quality of commitment}

Based on the results of multiple regression analyses showed that the value of a regression coefficient indicates a value of departure so that it can be interpreted that there is no relationship between competence and commitment. It is based also on the results of the hypothesis testing, the $\mathrm{T}$ count value for the competency variable is 1.061 when compared to the value of the This is 1.982 and the value of significance, $291>0.05$. Therefore, the $<$ This T count can be concluded that the competency variables have no positive and insignificant effect on the commitments. This means that $\mathrm{H} 1$ is rejected.

The results of a relationship strength analysis between dependent variables and independent variables or analyses to find out how large the free variables are to explain the bound variables, it is known that the coefficient of determination of Adjusted R Square of 0.444. This value means that a $44.4 \%$ variable regarding commitment is influenced by the competency and the rest is influenced by other variables.

Descriptive statistical testing results also show the average respondent's response to a low-value competency variable. The value shows that the capacity of human resources in the office of the Governor of South Sumatra province is insufficient. So it can be concluded that the human resources of civil apparatus officials of the state governor of South Sumatra province, most still have no impact on the commitment despite its competence has been enough.

ASN's commitment is one of the benchmarks for the governance of the area. A good ASN commitment can be determined by human resources in government organizations. Quality human resources, it will produce quality performance also. The success of an organization is not only influenced by human resources, but also human resources competence. Pujanira (2017) human resource competence is important in managing and presenting information, have good skills, a good attitude and carry out the task that is charged to him thereby maximizing his ability.

The results of this research are not in line with many previous studies that the competency positively affects the employee's commitment. This indicates that there is a problem in employee competence that should be positively influential. This finding indicates that there needs to be further mapping why competence has no positive effect on employee commitment.

\subsubsection{Effect of motivation on ASN commitment}

Based on the results of multiple regression analyses showed that the value of the regression coefficient indicates the positive value, so it can be interpreted that there is a relationship between the motivation to ASN commitments. It is based also on the results of the hypothesis testing, $\mathrm{T}$ count value for the variable 
motivation is 6.887 when compared to the value of this is 1.982 and the value of significance $0.000<0.05$. Then can be seen $\mathrm{T}$ count $>$ This so it can be concluded that the motivation variable has a positive and significant effect on commitment. This means that $\mathrm{H} 2$ is accepted.

The results of the analysis of the strength of the relationship between dependent variables with independent variables or analyses to find out how large the free variables are to explain the bound variables, it is well known that the determinations of the Adjusted R Square are 42.9 . This value means that a $42.9 \%$ variable about the ASN commitment is influenced by the motivation and the rest is influenced by other variables. Descriptive statistical testing results also show the average respondent's response to the motivation variable with a fairly high value. This means that in the dimension to motivation has fulfilled and well enough motivation of the ASN, but must remain improved again. The results of this study have not found any similarity of opinion on previous research, so it can be said this is new research.

\subsubsection{Leadership influence on ASN commitment}

Based on the results of multiple regression analyses indicate that the value of a regression coefficient shows positive value, so it can be interpreted that there is a relationship between leadership and commitment. It is based also on the results of the hypothesis testing, the $\mathrm{T}$ count value for the leadership variable is 3.147 when compared to the value of the This is 1.982 and the significance value is $0.002<0.05$. Then can be seen $\mathrm{T}$ count > this so Can be concluded that the leadership variables are positive and significant to the commitments. This means that $\mathrm{H} 3$ is acceptable.

The results of the analysis of the strength of the relationship between dependent variables with independent variables or analyses to find out how large the free variables are to explain the bound variables, it is well known that the determinations of the Adjusted R Square are 0.429 . This value means that a $42.9 \%$ variable regarding commitment is influenced by leadership and the rest is influenced by other variables. Descriptive statistical testing results also show the average respondent's response to a leadership variable with the highest value. It means leadership goes as it should and the leader has understood the principle in well but needs to be improved again.

$D$ Influence of competence, motivation, and leadership of ASN commitment

Based on the results of simultaneous regression tests, the F count value is 29.844 when compared to the $f$ table value is 2.685 and the significance value is $0.000<0.05$. Then can be seen F count down $>\mathrm{f}$ table so it can be concluded that the variable Competence, motivation, and leadership have a positive and significant impact on commitment. This means that $\mathrm{H} 4$ is received. In carrying out the government wheel, each area did the disagreements to achieve governance apparatus with good governance.

Governance with good governance can be seen from the commitment of the State civil apparatus in carrying out its obligations that are not only based on job completion but the ASN has a greater responsibility to realize Competitive and powerful performance enhancement. According [17], Human resource is an important factor to be able to realize a quality apparatus. The success of an entity is not only influenced by its human resources but also the competence of its human resources. To realize the commitment of the civil apparatus of the state of quality required a high commitment to accelerate the lag of other regions. important factor to be able to realize a quality apparatus. The success of an entity is not only influenced by its human resources but also the competence of its human resources. To realize the commitment of the civil apparatus of the state of quality required a high commitment to accelerate the lag of other regions.

\section{CONCLUSION}

This research aims to determine the competence, motivation, and leadership towards the commitment of the civil State apparatus in the office of the Governor of South Sumatera province. Based on the results of the research that has been outlined in the previous discussion the competence does not affect the ASN commitment in the office of the Governor of South Sumatera province. Motivation is positive and significant to the ASN commitment in the office of South Sumatera Province governor. Leadership is positive and significant to the ASN commitment in the office of South Sumatera Province governor. And the last competence, motivation, and leadership positively influence the ASN commitment to the office of the Governor of South Sumatera province. The advice in this study should be seen from the conclusion and the weakness can be described as follows: It is hoped that local leaders can pay attention to competence considering that the analysis has not had a positive relationship with the employee's commitment. Should be upgrading to the civil apparatus of the State to improve the competence of both knowledge, attitude, and skillset. In subsequent studies can add other independent variables that can influence the commitment and performance.

\section{REFERENCES}

[1] Harun, "Analisis Pengaruh Gaya Kepemimpinan dan Budaya Organisasi Pada Komitmen organisasi serta implikasinya terhadap kinerja pegawai negeri sipil dinas pendidikan se provinsi Sumatera Selatan," J. ecoment Glob., vol. 1, no. 1, pp. $63-$ 76, 2016.

[2] Budiyanto and H. W. Oetomo, "The effect of job motivation, work environment and leadership on organizational citizenship behavior, job satisfaction and public service quality in Magetan, East Java, Indonesia," World Acad. Sci. Eng. Technol., vol. 
75, no. 3, pp. 192-200, 2011.

[3] L. Baroroh, P. Budi, and M. Hamdani, "Pengaruh Motivasi Dan Kompetensi Profesional Terhadap Kinerja Pegawai Dengan Komitmen Organisasional Sebagai Variabel Moderasi," vol. 5, no. 1, pp. 38-46, 2017.

[4] A. Lotunani, M. S. Idrus, E. Afnan, and M. Setiawan, "The Effect of Competence on Commitment, Performance and Satisfaction with Reward as a Moderating Variable ( A Study on Designing Work plans in Kendari City Government, Southeast Sulawesi )," Int. J. Bus. Manag. Invent., vol. 3, no. 2, pp. 18-25, 2014.

[5] A. Fauzi, "Masyarakat, Meningkatkan Kinerja Aparatur Sipil Negara dalam Melayani," Diklat Rev., vol. 3, no. 1, 2019.

[6] T. A. J. Stephen P, Robbins, "Prilaku Organisasi," Salemba Empat, Jakarta, 2015.

[7] A.S.D. P. Utami and I. W. Suana, "Pengaruh Kepemimpinan Transaksional Dan Stres Kerja Terhadap Kepuasan Kerja Karyawan Pada PT. PLN (Persero) Area Bali Selatan," E-Jurnal Manaj. Unud, ISSN 2302-8912, vol. 4, no. 4, pp. 960-975, 2015.

[8] I Made Narsa, "Karakteristik Kepemimpinan: Transformasional versus Transaksional," J. Manaj. dan Kewirausahaan, vol. 14, no. 2, pp. 102-108, 2012.

[9] H. Handoko and F. Ciptono, "Kepemimpinan
Transformasional dan Pemberdayaan," J. Ekon. dan Bisnis Indones. Vol 13 No . 2 Tahun 1998, vol. 11, no. 1, 1996.

[10] Periansya, "Determinan Kepuasan kerja serta Implikasinya Pada Kinerja Dosen Perguruan Tinggi Negeri di Sumatera Selatan," UPI YAI, 2016.

[11] Sedarmayanti, Manajemen Sumber Daya Manusia Reformasi Birokrasi dan Manajemen Pegawai Negeri Sipil. Bandung: Refika Aditama, 2007.

[12] Rivai veithzal, Manajemen Sumber Daya Manusia Untuk Perusahaan. Jakarta: PT. Rajagrafindo Persada, 2009.

[13] G. Dessler, Manajemen Sumber Daya Manusia, Edisi 14. Jakarta: Salemba Empat, 2015.

[14] Khairul Umam, Perilaku Organisasi. Bandung: Pustaka Setia, 2010.

[15] K. Kreitner, Robert, Angelo, Prilaku Organisasi, Edisi 9. Jakarta: Salemba Empat, 2014.

[16] S. Edi, Manajemen Sumber Daya Manusia. Jakarta: Kencana, 2014.

[17] N. K. S. Wati, Kadek Desiana, Nyoman Trisna Herawati, "Pengaruh Kompetensi SDM, Penerapan SAP, Dan Sistem Akuntansi Keuangan Daerah Terhadap Kualitas Laporan Keuangan Daerah," eJournal S1 Akunt. Univ. Pendidik. Ganesha Jur. Akunt. Progr. S1, vol. 2, no. 1, 2014. 